\section{Пашковська Н.В.}

Буковинський державний медичний університет, м. Чернівці

\section{АВТОІМУННІ ЗАХВОРЮВАННЯ ЩИТОПОДІБНОЇ ЗАЛОЗИ І ВАГІТНІСТЬ}

Ключові слова: вагітність, антитіла до антигенів щчитоподібної залози, післяпологовий тиреоїдт

\begin{abstract}
Резюме. В статті представлені дані щзодо особливостей перебігу автоімунних захворювань щзитоподібної залози під час вагітності та у післяпологовому періодi, а також наведена інформація щуодо сучасних підходів до діагностики, лікування та профілактики тиреопатій у вагітних згідно останніх світових рекомендаџій, розроблених із позиџій доказової медиџини.
\end{abstract}

\section{Вступ}

Про те, що вагітність супроводжується збільшенням щитоподібної залози (ЩЗ), було відомо ще на зорі цивілізації. Так, у Давньому Єгипті заміжні жінки носили на шиї тоненьку нитку. Якщо вона рвалася, це розцінювалося як підтвердження факту вагітності. Згодом із горбом на шиї часто зображували Богоматір, особливо на старовинних візантійських і давньоруських іконах. Слід зауважити, що в епоху Відродження зоб взагалі вважався символом жіночої краси і певним атрибутом материнства.

Вплив вагітності на щитоподібну залозу

Збільшення розміру ЩЗ $є$ відображенням фізіологічних процесів в організмі, викликаних вагітністю. Так, зумовлене гіперестрогенемією посилення синтезу тироксин-зв'язувального глобуліну (ТЗГ) веде до зростання рівня загальних (пов'язаних із білками) гормонів, які на 6-8 тижні вагітності перевищують показники до вагітності майже в 1,5 раза та залишаються підвищеними до пологів. Відповідно до цього відбувається зниження вільних, біологічно активних гормонів із додатковою стимуляцією ЩЗ гіпофізом за принципом зворотного зв'язку [15].

Рівень тиреотропного гормону (ТТГ) впродовж першого триместру вагітності значно нижчий внаслідок перехресної реактивності хоріонічного гонадотропіну (ХГ). Справа в тому, що ХГ за структурою подібний до ТТГ: альфасубодиниці цих гормонів повністю гомологічні, бета - специфічні, що дозволяє ХГ зв'язуватися $з$ рецепторами ТТГ. Посилена продукція ХГ спричиняє підвищення рівня вільного тироксину (вT4) i, як наслідок, супресію ТТГ. Саме тому в клінічній картині міхурового заносу і хоріонкарциноми, що супроводжуються гіперсекрецією $\mathrm{XГ,} \mathrm{часто} \mathrm{відмічається} \mathrm{тиреотоксикоз.} \mathrm{Оскільки}$ продукція ХГ є максимальною на 9-11 тижні гестації, а далі поступово зменшується, рівні ТТГ, як правило, низькі у першому триместрі i зростають наприкінці вагітності [5]. Відповідно рівень вТ4 зазвичай найвищий у першому триместрі та знижується на пізніх термінах вагітності.

Периферичний метаболізм тиреоїдних гормонів також набуває специфічних змін. Плацента експресує дейодинази 2-го типу - селенозалежні ферменти, що здійснюють перетворення Т4 на $\mathrm{T} 3$, забезпечуючи компенсаторне підвищення рівня останнього, більш активного гормону. Крім того, у плаценті виробляються дейодинази 3-го типу, які трансформують Т4у реверсивний Т3 (рT3), а також Т3 у Т2 (дийодтирозин), тобто перетворюють тиреоїдні гормони на біологічно неактивні метаболіти. При цьому відбувається дейодування тиреоїдних гормонів матері, що дозволяє забезпечити плід додатковою кількістю йоду. Зважаючи на це, а також на зростання ниркового кліренсу йоду, материнський організм потребує додаткового надходження цього мікроелементу [15].

Рівні антитіл до антигенів ЩЗ знижуються протягом усього періоду гестації внаслідок фізіологічної імуносупресії, що властива вагітності [13].

У результаті зазначених природних змін інтерпретація показників функції ЩЗ у вагітних має певні особливості.

3 іншого боку, патологія Щ3 негативно впливає на перебіг вагітності, розвиток плода й адаптацію новонародженого. Тиреоїдна дисфункція загрожує викиднями, передчасними пологами, прееклампсією, післяпологовим тиреоїдитом у матері, а також зниженням інтелектуального потенціалу народжених дітей [3].

Отже, враховуючи все вищезазначене, питання 
коректної оцінки функції ЩЗ є надзвичайно важливим.

Особливості оцінки функиії щуитоподібної залози під час вагітності

На сьогодні питання коректної оцінки функції Щ3 під час вагітності є одним із найбільш дискусійних. Оскільки показники тиреоїдного гомеостазу зазнають специфічних змін упродовж різних термінів гестації, для вагітних жінок не можна застосовувати загальноприйняті норми рівнів Т3, Т4, ТТГ.

Зокрема, зважаючи на динаміку рівня ТТГ (зниження у першому триместрі вагітності із подальшим зростанням) сучасними рекомендаціями Американської асоціації тиреоїдологів (ATA, 2011) [4], Ендокринологічного товариства (ES, 2012) [1] наголошується на необхідності використання триместр-специфічних референтних діапазонів для цього гормону. Референтними діапазонами рівня ТТГ для першого триместру вагітності пропонується вважати значення $0,1-2,5$ мОд/л; другого - 0,2-3,0 мОд/л, третього - 0,3-3,0 мОд/л відповідно.

Як вже зазначалося, фізіологічний рівень загальних T3 і T4 у першому триместрі вагітності внаслідок гіперпродукції ТЗГ може у 1,5 раза перевищувати верхню межу норми невагітних. Тому ці показники не можна використовувати при оцінці функціонального стану ЩЗ вагітної.

3 іншого боку, оскільки визначення рівня в 4 утруднюється через високі рівні ТЗГ та зниження рівня циркулюючого альбуміну, що обмежує інформативність імуноаналізу [2], результати визначення цього гормону повинні інтерпретуватися 3 великою обережністю. Найбільш надійним для визначення вТ4 визнаний метод рідинної хроматографії у поєднанні із мас-спектрометрією (LC/MS/MS) [14], водночас використання його обмежене через низьку доступність.

Враховуючи все вищезазначене, найбільш коректним показником стану ЩЗ вагітних слід вважати сироватковий рівень ТТГ із урахуванням його триместр-специфічних референтних діапазонів. Проте визначення тільки одного показника позбавляє можливості дати всебічну оцінку тиреоїдної функції вагітної.

Враховуючи це, рекомендаціями ES (2012) зазначається необхідність пошуку альтернативних методів аналізу функції ЩЗ під час вагітності. Зокрема, пропонується визначення рівня загальних T4 і T3, але для інтерпретації результатів рекомендується заміна референсних діапазонів цих гормонів шляхом множення відповідних значень для невагітних на 1,5. Крім того, зазначається перспективність визначення індексу вільного тироксину, оскільки цей показник оцінюється з урахуванням зв'язувальних білків [1].

Антитіла до антигенів шүитоподібної залози і вагітність

Антитіла до тиреоїдної пероксидази і тиреоглобуліну виявляються в $10-20 \%$ жінок дітородного віку 13].У переважної більшості з них функція ЩЗ не порушена. Водночас навіть за умов еутиреозу в жінок із підвищеним рівнем АТТПО збільшується ризик передчасного переривання вагітності та розвитку післяпологових тиреопатій.

Так, показано, що частота викиднів у вагітних із нормальною функцією ЩЗ удвічі вища в разі наявності підвищених рівнів антитіл до ії антигенів [11].

В якості гіпотез, що висуваються з приводу цього питання, можна відмітити безпосередній вплив антитіл на взаємодію між плодом i плацентою, коливання рівня тиреоїдних гормонів, а також припущення, що антитіла до антигенів Щ3 становлять епіфеномен (побічний прояв) загального автоімунного процесу [10].

Із носійством антитіл до антигенів ЩЗ також пов'язані передчасні пологи, які становлять основну (після вроджених аномалій) причину неонатальної смертності і захворюваності. Зокрема, у АТ-ТПО-позитивних жінок відмічено зростання удвічі частоти передчасних пологів порівняно 3 вагітними без носійства антитіл. Серед причин передчасних пологів зазначається збільшення частоти передчасного розриву плодового міхура [16]. Проте, на думку експертів ATA і ES, на сьогоднішній день недостатньо даних для того, щоб рекомендувати або не рекомендувати скринінгове визначення рівня антитіл до антигенів ЩЗ у всіх вагітних у першому триместрі $[1,4]$.

Заслуговують на увагу результати рандомізованого контрольованого дослідження, під час якого АТ-ТПО-позитивним вагітним жінкам призначався лівотироксин. Авторами встановлене статистично значуще зменшення частоти як викиднів, так й передчасних пологів порівняно із групою жінок, які не отримували препарат [7]. Водночас лікування вагітних жінок із нормальною функцією ЩЗ та збільшеними рівнями АТ-ТПО за допомогою лівотироксину в даний час не передбачається жодними чинними рекомендаціями.

\section{Післяпологовий тиреоїдит}

Післяпологовий тиреоїдит представляє собою транзиторнудисфункцію ЩЗ у післяпологовому періоді, поширеність якої в середньому становить 
5,4\% [8]. Це захворювання є класичним прикладом деструктивного тиреоїдиту, до якого також належать підгострий тиреоїдит де Кервена, аміодарон індукований тиреотоксикоз 2-го типу та цитокініндукований (інтерфероновий) тиреоїдит.

Післяпологовий тиреоїдит розвивається внаслідок надлишкової реактивації імунної системи після природної гестаційної імуносупресії (феномен рикошету), що відбувається під час вагітності та в післяпологовому періоді [12]. Автоімунний генез захворювання підтверджується виявленням в пунктаті ЩЗ лімфоїдної інфільтрації, зв'язком із певними гаплотипами HLA і змінами в Т-клітинах, а також даними, згідно яких у близько $50 \%$ жінок зі збереженою функцією ЩЗ та підвищеними рівнями АТ-ТПО розвивається післяпологовий тиреоїдит. Слід зазначити, що жінки з цукровим діабетом 1 типу, автоімунними захворюваннями мають потрійний ризик виникнення післяпологового тиреоїдиту [8].

Класичним проявом післяпологового тиреоїдиту є транзиторний тиреотоксикоз. Справа в тому, що колоїд фолікулів ЩЗ містить велику кількість тиреоїдних гормонів, якої було б достатньо для забезпечення організму протягом 2-3 місяців. Унаслідок зумовленої автоімунним процесом фолікулярної деструкції надлишок тиреоїдних гормонів потрапляє в кровоносне русло, зумовлюючи симптоматику тиреотоксикозу.

Тиреотоксична фаза характеризується транзиторним тиреотоксикозом, що розвивається приблизно через 8-12 тижнів після пологів і триває до 2 місяців. Далі настає стадія транзиторного гіпотиреозу, з подальшим поверненням до еутиреоїдного стану протягом першого року після пологів. Гіпотиреоїдна фаза розвивається в середньому на 19-му тижні після пологів, триває близько 4-6 місяців, супроводжується гіпотиреоїдною симптоматикою. Тривалість гіпотиреоїдної фази досить варіабельна.

Слід зауважити, що зазначений трифазний перебіг, який становить класичну картину післяпологового тиреоїдиту, насправді відмічається тільки у $22 \%$ усіх жінок.У $30 \%$ випадків розвивається ізольований тиреотоксикоз із поверненням до еутиреозу впродовж року після пологів. Найбільш поширеним варіантом, який трапляється у $48 \%$ жінок, $\epsilon$ ізольована фаза гіпотиреозу, яка в подальшому спонтанно минає. Таким чином, у більшості жінок упродовж року після пологів відбувається відновлення еутиреоїдного стану. Приблизно в $30 \%$ АТ-ТПОпозитивних жінок, в яких виник післяпологовий тиреоїдит, гіпотиреоїдна фаза переходить у стійкий гіпотиреоз і вимагає постійної замісної терапії тиреоїдними препаратами [13].

У більшості пацієнток тиреотоксична фаза післяпологового тиреоїдиту перебігає безсимптомно. Клінічними проявами $є$ непереносимість спеки, серцебиття, втома і дратівливість, більшість 3 яких відмічаються під час нормального післяпологового періоду. Гіпотиреоїдна фаза має більш виражені клінічні прояви, серед яких частіше відмічається порушення концентрації уваги, астенія, підвищена втомлюваність, сухість шкіри, непереносимість холоду, схильність до закрепів [6].

Питання зв'язку післяпологового тиреоїдиту та післяпологової депресії залишається дискусійним. Доведено, що на тлі гіпотиреоїдної фази тиреоїдиту ризик розвитку малих і великих депресій зростає. Виходячи з цього, жінкам із післяпологовою депресією рекомендується визначення рівня ТТГ, вТ4 і АТ-ТПО [4]. Водночас призначення лівотироксину АТ-ТПО-позитивним жінкам не впливає на розвиток післяпологової депресії [9].

Особливості ведення жінок із післяпологовим тиреоїдитом залежать від тяжкості симптомів, тривалості дисфункції ЩЗ, можливості здійснювати грудне вигодовування або планування жінкою нової вагітності [13].

Оскільки тиреотоксична фаза носить транзиторний і завжди минущий характер, лікування іiі повинно бути симптоматичним, при цьому препаратами вибору є бета-адреноблокатори (пропранолол) у мінімально можливих дозах. Зазвичай така терапія триває кілька місяців. Враховуючи деструктивний характер тиреотоксикозу, тиреостатичні препарати не призначаються [4].

3 метою своєчасного виявлення гіпотиреоїдної фази після завершення стадії тиреотоксикозу впродовж першого року після пологів раз на 2 місяці необхідно оцінювати рівень ТТГ (або при появі симптомів гіпотиреозу).

Лікування лівотироксином у фазі гіпотиреозу показане в разі зростання рівня ТТГ $>10,0$ мОд/л, коли рівень ТТГ підвищений більш ніж 6 місяців або якщо жінка здійснює грудне вигодовування або намагається завагітніти. Терапія повинна здійснюватися згідно правил замісної терапії для гіпотиреозу будь-якого генезу і тривати впродовж 6-12 місяців, після чого відміняється [4].

Жінки, які перенесли післяпологовий тиреоїдит, що завершився еутиреозом наприкінці першого року після народження дитини, перебувають у групі підвищеного ризику розвитку гіпотиреозу i потребують постійного моніторингу із щорічним визначенням ТТГ. Частота розвитку стійкого 
гіпотиреозу через 3-12 років після епізоду післяпологового тиреоїдиту становить 20-40\% [8].

Література. 1. De Groot L. Management of thyroid dysfunction during pregnancy and postpartum: an Endocrine Society clinical practice guideline / L. DeGroot // J. Clin. Endocrinol. Metab. - 2012. - Vol. 97, №8. - P. 2543-2565. 2

Free T4 immunoassays are flawed during pregnancy / R. H Lee, C. A. Spencer, J. H. Mestman [et al.] // Am. J. Obstet. Gynecol. - 2009. - Vol. 200, №3. - P. 260. 3.Glinoer D. The regulation of thyroid function i npregnancy: pathways of endocrine adaptation from physiology to pathology / D Glinoer // Endocr. Rev. - 1997. - Vol. 18, №3. - P. 404-433. 4. Guidelines of the American Thyroid Association for the diagnosis and management of thyroid disease during pregnancy and postpartum / A. Stagnaro-Green, M. Abalovich, E. Alexander [et al.] // Thyroid. - 2011. - Vol. 21, №10. - P. 10811125. 5. Hershman J. M. Physiological and pathological aspects of the effec to $\mathrm{f}$ human chorionicgonadotropin on the thyroid / J. M. Hershman // BestPract. Res. Clin. Endocrinol. Metab. - 2004. - Vol. 18, №2. - P. 249-265. 6. Lazarus J. H. Clinical manifestations of postpartum thyroid disease / J. H. Lazarus // Thyroid. - 1999. - Vol. 9, №7. - P. 685-689. 7. Levothyroxine treatment in euthyroid pregnant women with autoimmune thyroid disease: effects on obstetrical complications /R. Negro, G. Formoso, T. Mangieri [et al.] // J. Clin. Endocrinol. Metab. - 2006. -Vol.91, №7. - P. 2587-2591. 8. Muller A. F. Postpartum thyroiditis and autoimmune thyroiditis in women of childbearing age: recent insightsand consequences for antenatal and postnatal care / A. F.Muller, H. A. Drexhage, A. Berghout // Endocr. Rev. -2001. - Vol. 22, №5 - P. 605-630. 9. Randomised trial of thyroxine to prevent postnatal depression in thyroid-antibody-positive women / B. Harris, R. Oretti, J. Lazarus [et al.] // Br. J. Psychiatry. - 2002. - Vol. 180. - P. 327-330. 10. Risk of spontaneous miscarriage in euthyroid women with thyroid autoimmunity undergoing IVF: a meta-analysis / K. A. Toulis, D. G. Goulis, C. A. Venetis [et al.] // Eur. J. Endocrinol. - 2010. - Vol. 162. - P. 643-652. 11. Stagnaro-Green A. Thyroid antibodies and miscarriage: where are we at a generation later? / A. Stagnaro-Green // J. ThyroidRes. - 2011. - Vol. 2011. - P. 841 - 949. 12.StagnaroGreen A. Optimal care of the pregnant woman with thyroid disease / A. Stagnaro-Green // J. Clin. Endocrinol. Metab. 2012. - Vol. 97, № 8. - P. 2619-2622. 13. Stagnaro Green A. Thyroid disorders in pregnancy / A. Stagnaro-Green, E. Pearce // Nature Reviews Endocrinology. - 2012. - Vol. 8. - P. 650-658. 14. Tandem massspectrometry improves the accuracy of free thyroxine measurements during pregnancy / $\mathrm{N}$. Kahric-Janicic, S. J. Soldin, O.P. Soldin [et al.] // Thyroid. 2007. - Vol. 17, №4. - P. 303-311. 15. Thyroid function and human reproductive health / G. E. Krassas, K. Poppe, D. Glinoer [et al.] // Endocr. Rev. - 2010. - Vol. 31, № 5. - P. $702-$ 755. 16. Thyroperoxidase and thyroglobulin antibodies in early pregnancy and preterm delivery / J.E. Haddow, J. ClearyGoldman, M.R. McClain [et al.] // Obstet. Gynecol. - 2010. Vol. 116, №1. - P. 58-62.

\section{АУТОИММУННЫЕ ЗАБОЛЕВАНИЯ ЩИТОВИДНОЙ ЖЕЛЕЗЫ И БЕРЕМЕННОСТЬ}

\section{Н.В. Пашковская}

Резюме. В статье представлены литературные данные об особенностях течения аутоиммунных заболеваний щитовидной железы во время беременности и в послеродовом периоде, а также приведена информация о современных подходах к диагностике, лечению и профилактике тиреопатий у беременных женщин согласно последних мировых рекомендаций , разработанных с позиций доказательной медицины.

Ключевые слова: беременность, антитела к антигенам щитовидной железы , послеродовой тиреоидит

\section{AUTOIMMUNE THYROID DISEASE AND PREGNANCY} N.V.Pashkovska

Abstract. The article presents literary data on the peculiarities of autoimmune thyroid disease during pregnancy and in postpartum period, and provides information on current approaches to diagnostics, treatment and prevention of thyropathies in pregnant women according to the latest international recommendations developed from the positions of demonstrated medicine.

Key words: pregnancy, antibodies to thyroid antigens, postpartum thyroiditis

Bukovyna State Medical University (Chernivtsi)

Clin. and experim. pathol.- 2014.- Vol.13, №1 (47).-P.187-190. Надійила до редакиії 17.02.2014

Рецензент - проф. О. В. Кравченко

(С) Н.В.Пашковська, 2014 